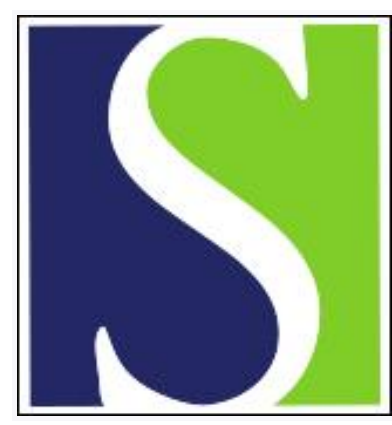

Scand J Work Environ Health 2003;29(4):314-316

https://doi.org/10.5271/sjweh.736

Issue date: Aug 2003

\title{
Mites in facilities for laboratory animals
}

by Pennanen SMA, Harju ATK

Affiliation: Kuopio Regional Institute of Occupational Health, Laboratory of Environmental Microbiology, PO Box 93, FIN-70701 Kuopio, Finland. sirpa.pennanen@ttl.fi

Key terms: indoor allergen; laboratory animal; laboratory animal worker; mite; pilot study; short communication; storage mite

This article in PubMed: www.ncbi.nlm.nih.gov/pubmed/12934725

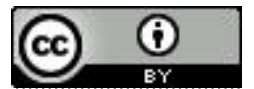




\title{
Mites in facilities for laboratory animals
}

\author{
by Sirpa MA Pennanen, PhD, ${ }^{1}$ Anu TK Harju, $P h D^{1}$
}

\begin{abstract}
Pennanen SMA, Harju ATK. Mites in facilities for laboratory animals. Scand J Work Environ Health 2003;29(4): 314-316.

Objectives Two laboratory animal facilities were examined for storage and house-dust mites.

Methods Samples of settled dust or material were investigated microscopically, and all of the found mites were identified.

Results Every fourth sample contained mites. On the average, 86 mites were found in a gram of dust. Measurement with a two-way enzyme-linked immunosorbent assay revealed only one sample containing a minor amount of allergen from Dermatophagoides pteronyssinus.

Conclusions It seems that, in addition to house-dust mites, other mites may be important occupational contaminants in animal facilities.
\end{abstract}

Key terms indoor allergen, laboratory animal workers, pilot study, storage mites.

Occupational environments contain several biological agents and materials that can potentially induce health problems (1), for example, allergens of mites and animals. About one-third of laboratory animal workers has occupational allergy to animal dander, and a third has symptomatic asthma (2-4).

Information about the occupational exposure of laboratory animal workers to rat and mouse urine proteins has recently become available (5-8). House-dust mites, together with cat and dog allergens, have been considered the most important indoor factors increasing the risk of allergic reactions. In addition, storage mites have been documented as a cause of allergic symptoms, especially in cases of rural occupational exposure at sites such as farms, dairy barns, and grain elevators (9-16). However, nothing is known about the occupational exposure of laboratory animal workers to mites. Similarly, the occurrence of mite fauna in dust from laboratory animal facilities has not been studied.

The aim of this study was to survey the mite fauna in two different animal facility centers and determine the common indoor allergen level in the animal facility environment.

\section{Materials and methods}

Dust sampling. Two laboratory animal facilities were surveyed for storage and house-dust mites. The settled dust was vacuumed $\left(1 \mathrm{~min} / \mathrm{m}^{2}\right)(17)$ or brushed from floors and animal cages, and samples of food and bedding were collected. Samples were also collected from the lounge chairs. Altogether 20 samples $(12+8)$ were collected.

Dust samples for allergen analyses (Der p 1 for Dermatophagoides pteronyssinus) were also collected by vacuuming the settled dust onto cellulose acetate or cellulose nitrate filters (Millipore AAWP09025 AA, pore size $0.8 \mu \mathrm{m}$, Millipore Corporation, Bedford, MA, USA) (18). Two allergen samples were collected from each facility.

Mite analysis. From each sample, two subsamples of 25 to 50 milligrams of dust were taken for the counting and identification of mites. After the mites were clarified in lactic acid, they were picked out under a stereomicroscope at low magnification $(\times 13-80)$. The mites were mounted in Heinze polyvinyl alcohol medium and 
subsequently counted and identified under a microscope ( $\times 40-400)$. Mites were identified by a biologist with several years of experience in mite identification. The results were calculated as the number of mites in a gram of dust. If no mites were found in a sample, a detection limit (DL) was calculated by using the equation $1 / \mathrm{M}$, where $\mathrm{M}$ is the mass of dust. For the calculations, a value of DL/2 was used for these samples.

Allergen analysis. The Der $\mathrm{p} 1$ content of the dust was analyzed by the two-way enzyme-linked immunosorbent assay, as described earlier (19). All allergen-specific reagents and standards were purchased from Indoor Biotechnologies Ltd, Cardiff, United Kingdom. The detection limit for Der p 1 was $0.080 \mathrm{ng} / \mathrm{ml}$. The results were calculated from the straight part of the standard curves, and the allergen levels were expressed as the mean of duplicate measurements (micrograms of allergen per gram of original dust).

\section{Results}

Out of the 12 samples collected from facility A, two $(16.7 \%)$ contained mites (table 1). On the average, 86 mites were found per gram of dust. Mites were found in samples from the feed storage floor and from a lounge chair. Most of the mites were storage mites, belonging to Astigmata species (Glycyphagidae, Acaridae) or Prostigmata species (Tarsonemus $s p$, Cheuyletus $s p$ ). Mite allergens were not found in the two collected samples. In facility B, three of the eight samples (37.5\%) contained mites. On the average, 87 mites were found per gram of dust. Mites were found in samples from the feed and bedding storage floors and from a lounge chair. Astigmata or Prostigmata species were again the species most often found. Only one house-dust mite, Dermatophagoides species, was found (sample from a staff room chair), comprising $2.6 \%$ of the mites found. One of the two allergen samples contained Der $\mathrm{p} 1$ at a concentration of $0.002 \mathrm{~g} / \mathrm{g}$.

\section{Discussion}

Laboratory animal allergy is a common occupational hazard for people working with laboratory animals. More potential animal allergens, especially for the general population, are the indoor mites (ie, house-dust and storage mites). Thus far, nothing is known about the occurrence of mites in laboratory animal facilities. In our study, $25 \%$ of the collected samples contained mites. Mites were found both in samples from staff room chairs and in samples from the storage areas of the two inspected facilities. This finding shows that mites can be found
Table 1. Number of mites (mites/g of dust) and species found in two laboratory animal facilities.

\begin{tabular}{|c|c|c|c|c|c|c|c|}
\hline \multirow[t]{3}{*}{ Facility } & \multicolumn{3}{|c|}{ Sample } & \multicolumn{3}{|c|}{ Mites/gram of dust } & \multirow[t]{3}{*}{ Species $^{a}$} \\
\hline & \multirow[t]{2}{*}{$\mathrm{N}$} & \multicolumn{2}{|c|}{ Positive } & \multirow[t]{2}{*}{ Mean } & \multirow[t]{2}{*}{ SD } & \multirow[t]{2}{*}{ Median } & \\
\hline & & $\mathrm{N}$ & $\%$ & & & & \\
\hline A & 12 & 2 & 16.7 & 86 & 140 & 56 & $\begin{array}{l}\text { Gycyphagidae (2), un- } \\
\text { known (4) }\end{array}$ \\
\hline B & 8 & 3 & 37.5 & 87 & 98 & 43.5 & $\begin{array}{l}\text { Acaridae(1), } \\
\text { Gycyphagidae (1), } \\
\text { Dermatophagoides (1), } \\
\text { Tarsonemus (11), } \\
\text { Cheyletidus (15), } \\
\text { Eriophyidae (1), } \\
\text { Unknown (3) }\end{array}$ \\
\hline
\end{tabular}

a Number of mites given in parentheses.

throughout the premises. However, no mites were found in the animal rooms themselves, probably partly due to the small sample sizes and partly due the fact that the rooms are cleaned more frequently and thoroughly than storage rooms and other areas. The mites seem to spread, most likely from animal food or bedding, since the same species were found in both the staff rooms and the storage rooms. Mites spread quickly and thoroughly (20). On the average, 86 mites were found per gram of dust. In two cases (feed storage room and staff room chair in facility B), the mite density exceeded the suggested sensitization threshold of 100 mites/g dust (21). Most of the mites were storage mites, belonging to Astigmata or Prostigmata species. The levels of dust mite allergen (Der p 1) were low in comparison with the concentrations generally measured in house dust in homes (22-23). Our results suggest that mites may be important allergenic agents also in laboratory animal facilities. Since storage mites were particularly numerous, they may, in fact, be more important indoor allergens than previously believed. Attention should be paid to proper cleaning practices and protection against mites. The allergens from the storage mite Lepidoglyphus destrutor, such as Lep d 1 and Lep d 2, have been purified and characterized, and a method for measuring allergens in dust samples has been developed (24-28). Furthermore, we need new commercial methods for measuring storage mite allergens in order to study comprehensively the possible role of mites in sensitizing laboratory animal workers.

\section{Acknowledgments}

This work was supported by the Finnish Work Environment Fund. 


\section{References}

1. Dutkiewicz J, Jablonski L, Olenchock SA. Occupational Biohazards: a review. Am J Ind Med 1988;14:605-23.

2. Newman Taylor AJ, Gordon S. Laboratory animal and insect allergy. In: Berstein IL, Chan-Yeung M, Malo J-L, Bernstein DI, editors. Asthma in the workplace. New York (NY): Marcel Dekker Inc; 1993. p 399-414.

3. Huskaar S, Fosse RT. Allergy and laboratory mice and rats: a review of the pathophysiological, epidemiological and clinical aspects. Lab Anim 1990;24:358-74.

4. Ross DJ, Sallie BA, Mc Donald JC. SWORD'94: surveillance of work-related and occupational respiratory disease in the UK. Occup Med 1995;45:175-8.

5. Gordon S, Tee RD, Nieuwenhuijsen MJ, Lowson D, Harris J, NewmanTaylor AJ. Measurement of airborne rat urinary allergen in an epidemiological study. Clin Exp Allergy 1994;24: $175-8$.

6. Nieuwenhuijsen MJ, Gordon S, Tee RD, Venables KM, McDonald JC, NewmanTaylor AJ. Exposure to dust and rat urinary allergen in research establishments. Occup Environ Med 1994;51:593-6.

7. Ohman JL, Hagberg K, MacDonald MR, Jones RR Jr, Paigen BJ, Kacergis JB. Distribution of airborne mouse allergen in a major breeding facility. J Allergy Clin Immunol 1994;94:810 7.

8. Gordon S, Kiernan LA, Nieuwenhuijsen MJ, Cook AD, Tee RD, NewmanTaylor AJ. Measurement of exposure to mouse urinary protein in an epidemiological study. Occup Environ Med 1997;54:135-40.

9. Cuthbert OD, Brostoff J, Wraith DG, Brighton WD. 'Barn allergy': asthma and rhinitis due to storage mites. Clin Allergy 1979;9:229-36.

10. Warren CP, Holford V, Sinha RN. Sensitization in a grain handler to the storage mite Lepidoglyphus destructor. Ann Allergy 1983;1983:30-3.

11. van Hage-Hamsten M, Johansson SGO, Hoglund S, Tull P, Wiren A, Zimmerstron O. Storage mite allergy is common in a farming population. Clin Allergy 1985;15:555-64.

12. Blainey AD, Topping MD, Ollier S, Davies RJ. Allergic respiratory disease in grain workers: the role of storage mites. $\mathrm{J}$ Allergy Clin Immunol 1989;84:296-303.

13. Revsbech P, Dueholm M. Storage mite allergy among bakers. Allergy 1990;45:204-8.

14. Iversen M, Korsgaard T, Hallas T, Dahl R. Mite allergy and exposure to storage mites and house dust mites in farmers. Clin Exp Allergy 1990;20:211-9.

15. Reijula K, Patterson R. Occupational allergies in Finland in 1981-1991. Allergy Proc 1994;15:163-8.
16. Radon K, Schottky A, Garz S, Koops F, Szadkowski D, Radon K, et al. Distribution of dust-mite allergens (Lep d2, Der p 1, Der f1, Der 2) in pig-farming environments and sensitization of the respective farmers. Allergy 2000;55:21925.

17. Platts-Mills TAE, Hayden ML, Chapman MD, Wilkins SR. Seosanal variation in dust mite and grass-pollen allergens in dust from the houses of patients with asthma. J Allergy Clin Immunol 1987;79:781-91.

18. Pennanen S, Harju A, Merikoski R, Pasanen A-L, Liesivuori J. Occupational exposure to indoor allergens in Finnish trained home-helpers: a pilot study. J Occup Health 2002;44:140-4.

19. Raunio P, Pasanen A-L, Reiman M, Virtanen T. Cat, dog, and house-dust-mite allergen levels of house dust in Finnish apartments. Allergy 1998;53:195-9.

20. Mollet JA, Robinson WH. Dispersal of American house dust mites (Acari: Pyroglyphidae) in a residence. J Med Entomol 1996; 3:844-7.

21. Platts-Mills TAE, Thomas WR, Aalberse RC, Vervloet D, Chapman DM. Dust mite allergens and asthma: report of a second international workshop. J Allergy Clin Immunol 1992; 89:1046-60.

22. Janko M, Gould DC, Vance L, Stengel C, Flack J. Dust mite allergens in the office environment. AIHA J 1995;56:113340.

23. Lundblad F. House dust mite allergy in an office building. Appl Occup Environ Hyg 1991;6:94-6.

24. Ventas P, Carreira J, Polo F. Cuantificación del alergeno mayritario de L. destructor (Lep p1) mediante anticuerpos monoclonales. Res Esp Alergol Inmunol Clin 1990;5 Suppl 3:88.

25. Varela J, Ventas P, Carreira J, Barbas JA, Gimenez-Gallego G, Polo F. Primary structure of Lep d1, the main Ledidoglyphus destructor allergen. Eur J Biochem 1994;225:93-8.

26. Echechipía S, Ventas P, Audícana M, Urrutia I, Gastaminza G, Polo F, et al. Quantitation of major allergens in dust samples from urban populations collected in different seasons in two climatic areas of the Basque region. Allergy 1995;50:47882.

27. Plácido JL, Cueasta C, Delgato L, Moreira da Silva JP, Miranda $\mathrm{m}$, Ventas $\mathrm{P}$, et al. Indoor mite allergens in patients with respiratory allergy in Porto, Portugal. Allergy 1996;51:633-9.

28. Parvaneh S, Johannsson E, Elfman LHM, van Hage-Hamsten M. An ELISA for recombinant Lepidoglyphus destructor, Lep $\mathrm{d} 2$, and the monitoring of exposure to dust mite allergens in farming households. Clin Exp Allergy 2002;32:80-6.

Received for publication: 18 March 2003 